\title{
HEALTH MANAGEMENT IN BRAZIL: DIALOGUE WITH PUBLIC AND PRIVATE MANAGERS
}

\author{
Jorge Lorenzetti ${ }^{1}$, Gabriela Marcellino de Melo Lanzoni², Luciana Ferreira Cardoso Assuiti ${ }^{3}$ Denise Elvira \\ Pires de Pires ${ }^{4}$, Flávia Regina Souza Ramos ${ }^{5}$
}

${ }^{1}$ Ph.D. in Nursing. Professor at the Nursing Department of the Federal University of Santa Catarina (UFSC). Santa Catarina, Brazil. E-mail: jorgelorenzetti@hotmail.com

${ }^{2}$ Ph.D. in Nursing. Nurse at the Santa Catarina State Health Department. Santa Catarina, Brazil. E-mail: gabimrc@gmail.com

${ }^{3}$ Doctoral Student at the UFSC Nursing Graduate Program (PEN). Santa Catarina State, Brazil. E-mail: lufono@hu.ufsc.br

${ }^{4}$ Ph.D. in Social Sciences. Professor at the Nursing Department and at PEN/UFSC. Santa Catarina, Brazil. E-mail: piresdp@ yahoo.com.

${ }^{5}$ Ph.D. in Nursing Philosophy. Professor at the Nursing Department and at PEN/UFSC. Santa Catarina, Brazil. E-mail: flaviar@ ccs.ufsc.br

ABSTRACT: The aim of this study was to identify the main health management issues in Brazil according to the opinion of managers who were intentionally chosen. Data was collected from July to November 2010, through key-informant interviews: two directors from national reference private hospitals, located in Southeast Brazil; and executive authorities of the Brazilian Unified Health System (SUS), one of each government level - municipal, state, and federal managers. SUS management was considered outdated; the system was defined as lacking stable funding and having flaws in planning and service assessment. Moreover, both sectors lack professionalization in management. In conclusion, SUS is still in consolidation and requires more resources, stable funding and management able to bring its principles and guidelines into reality. Management issues affect both public and private sectors and the public-private partnerships have not been oriented by public responsibility.

KEYWORDS: Unified Health System. Health systems. Health management. Health services administration. Organization and administration.

\section{GESTÃO EM SAÚDE NO BRASIL: DIÁLOGO COM GESTORES PÚBLICOS E PRIVADOS}

\begin{abstract}
RESUMO: Estudo com objetivo de identificar os principais problemas da gestão em saúde no Brasil, a partir da opinião de gestores escolhidos intencionalmente. Os dados foram coletados entre julho e novembro de 2010, através de entrevistas com informantes chave: dois diretores de hospitais privados de referência nacional, localizados na região sudeste; e autoridades executivas do SUS, um de cada esfera de governo, municipal estadual e da direção nacional. A gestão do SUS foi considerada desatualizada, o sistema carente de financiamento estável e com déficits no planejamento e na avaliação dos serviços. A falta de profissionalização da gestão foi identificada nos dois setores. Conclui-se que o SUS está em consolidação carecendo de mais recursos, financiamento estável e de gestão capaz de transformar os seus princípios e diretrizes em realidade; que os problemas de gestão também afetam o setor privado e que as parcerias público-privado não têm sido regidas pela responsabilidade pública.
\end{abstract}

PALAVRAS CHAVE: Sistema Único de Saúde. Sistemas de saúde. Gestão em saúde. Administração de serviços de saúde. Organização e administração.

\section{LA GESTIÓN DE SALUD EN BRASIL: DIÁLOGO CON GESTORES PÚBLICOS Y PRIVADOS}

RESUMEN: Estudio cuyo objetivo fue identificar los principales problemas de gestión de salud en Brasil, a partir de la opinión de gestores seleccionados intencionalmente. Los datos fueron recolectados entre julio y noviembre del 2010, a través de entrevistas con informantes clave: dos directores de hospitales nacionales privados localizados en la región sudeste y los otros tres fueron autoridades ejecutivas del Sistema Único de Salud (SUS) de cada esfera gubernamental (municipal, estatal y dirección nacional). La gestión del SUS fue considerada desactualizada, el sistema es carente de financiamiento estable y con déficit de planeamiento y evaluación de los servicios. La falta de profesionalización de gestión fue identificada en ambos sectores. Se concluye que el SUS está en consolidación, careciendo de recursos financieros estables y de gestión capaz de transformar su principios y directrices en realidades tangibles, que los problemas de gestión también afectan al sector privado y que las asociaciones público-privadas no han sido regidas por la responsabilidad pública.

PALABRAS CLAVE: Sistema Único de Salud. Sistemas de salud. Gestión en salud. Administración de los servicios de salud. Organización y administración. 


\section{INTRODUCTION}

Recent surveys have demonstrated healthcare as the main concern of people. In some situations and countries, it only stays behind economic issues, such as, unemployment and insufficient incomes. ${ }^{1-3}$ Such relevance turns policy, actions and healthcare services increasingly important into the contemporary societies agenda.

The World Health Organization (WHO) admits that in order to meet the expectations of the population it is essential to ensure a universal coverage targeted to promotion, protection and recovery of health. ${ }^{1}$ In the United States of America, where healthcare expenses have already achieved $16 \%$ of the Gross Domestic Product (GDP), ${ }^{4}$ healthcare has become one of the main internal issues.

In Brazil, the expectations and dissatisfaction of the population concerning healthcare services is constantly increasing, and it figures as the top complaint or issue. In September 2010, a survey involving eight of the largest Brazilian states has appointed healthcare as the main issue, achieving the average of $32.8 \%$ among the states, reaching $54 \%$ in the Federal District and 25\% in Pernambuco state. Safety is the second main concern of the population, achieving the average of $23.2 \%$, followed by education, with the average of $10 \%{ }^{3}$ In 2011, healthcare figured as the main issue again, reaching $52 \%$ of indications. ${ }^{2}$

Although such surveys do not result from a technical assessment of healthcare services efficiency and effectiveness, they express the opinion and perception both of users and the overall population, and consist in an important indicator to all of the people involved in healthcare policies and practices improvement, especially health professionals and professors, governments, managers, healthcare institutions and media.

The weaknesses in management and underfunding have emerged as relevant issues for analysis conducted by scholars and managers. In the case of underfunding, a decreasing participation of the public sector in healthcare expenditures is highlighted in Brazil. In 1995, among the total amount spent in healthcare services, $62 \%$ were covered by the public sector and $38 \%$ by the private sector; however, in 2009, the public sector expenses decreased to $47 \%$ and the private sector took $53 \%$ of the expenses. ${ }^{3}$

Criticisms towards health management in Brazil are extensive, varied and demonstrate the dimension of the issues yet to be faced. With regard to the Brazilian hospital network, the "existence of several healthcare institutions with severe management weakness" have already been diagnosed, which are far from meeting the requirements for providing 'a resolutive, adequate and improved care', "and far too little is known concerning the quality of the services provided". 5:47

Among the contemporary institutions, the hospital is perceived as one of the most resistant to changes due to the low levels of interaction between professions and departments, fragmentation of clinical practices, large subordination of users to healthcare services and little authority of managers to act upon corporations. "Hospitals could be considered the Sphinx of modern management theories because up to this moment neither their logic of reproduction was properly revealed, nor alternative routes were appointed to redesign such tradition".$^{6: 23}$

Health management/administration can be defined as the knowledge applied to handling complex healthcare organizations, which involves the management of networks, healthcare public spheres, hospitals, laboratories, clinics and other institutions and healthcare services. It comprises three large highly complex dimensions: direct care areas - singular and multiprofessional; several healthcare institutions; and the demand for training and operation at the healthcare service networks aiming at providing a universal, comprehensive, equitable, high quality and efficient care meeting the health needs of the population. ${ }^{\text {? }}$

It is a recurrent finding that health management is still supported in traditional methods and strategies deriving from classical management theory. Also, developing new methods for management in healthcare areas based on participation, cooperative and interdisciplinary practices, and in which both professional and users act as active individuals, still remains a challenge. ${ }^{8}$

In Brazil, from the 80's onwards, after the 1988 Constitution drawing up and the Unified Health System (SUS) development, actions and services related to healthcare were institutionalized as public policy and healthcare was established as a right for all and an obligation of the government. Such survey was motivated by the relevance of the healthcare agenda within the Brazilian society and the management issue which was highlighted as one of the structural aspects of the challenges for the positive transformation of the current situation in which healthcare is found. Therefore, based on the opinion of managers, the 
aim of this study was identify and reflect over the main issues or weaknesses related to health management in Brazil.

\section{METHODOLOGY}

This is a qualitative study in which data were collected between July and November 2010 by means of semi-structured interviews conducted with key informants, managers of Brazilian healthcare institutions. The sample was intentionally composed by two managers of private hospitals whose high quality care provided is a national reference, and three managers from SUS (from municipal, state and national levels). The reduc- tion and the total number of interviewees selected entailed considering only analysis factors related to experience in health management without discriminating singularities from different sectors/levels or deepening factors that characterize the diversity and complexity of several management areas.

In the private sector, the interviews were conducted with directors of leading hospitals located in Southeast Brazil and, in the public sector, the interviews were conducted with two Health Departments in Southern Brazil (one from municipal level and another from state level), in addition to an authority of the Ministry of Health. Figure 1 demonstrates the sample composition and characterization.

Figure 1 - Location of activity and profile of the individuals involved in this study

\begin{tabular}{|c|c|l|}
\hline Interviewee & Level & \multicolumn{1}{|c|}{ Profile } \\
\hline Manager 1 & Municipal & $\begin{array}{l}\text { Physician, City Health Department, with experience in management of the three } \\
\text { levels of SUS. }\end{array}$ \\
\hline Manager 2 & National & $\begin{array}{l}\text { Physician with experience in management of the state and national levels and mem- } \\
\text { ber of the managerial decision staff of the Ministry of Health. }\end{array}$ \\
\hline Manager 3 & State & Physician with experience in management of the state level. \\
\hline Manager 4 & Private Sector & Physician with experience in management of the private sector. \\
\hline Manager 5 & Private Sector & Administrator. Experience in the automotive field and private sector of healthcare. \\
\hline
\end{tabular}

The interviews were conducted in the workplace of the participants and they were both recorded and fully transcribed in order to be further analyzed according to the thematic analysis guidelines. Semi-structured interviews were chosen because such format allows flexibility when using key guidelines and also the emergence of new questions during the interaction between the interviewee and the researcher, and such questions may contribute to better capture the diverse dimensions related to complex phenomena. ${ }^{9}$ The guideline was composed by nine questions addressed to the management situation, both local (manager's field of activity) and national situations, management model, management tools, initiatives or innovative solutions for health management.

Data analysis was conducted accordingly to the operation of the three steps of thematic analysis. ${ }^{10}$ The first step, also known as pre-analysis, consisted of the comprehensive reading of each interview conducted (first reading), followed by the material's organization (elaboration of the corpus) and hypothesizing. The second step involved the material's exploration in which raw data were encoded. Finally, the treatment and interpretation of the outcomes were performed, which were pre- sented through thematic units. Data analysis and interpretation allowed recognizing relevant structures which led to the identification of primary and family codes, allowing the construction of five thematic units presented through textual parts.

The research project was submitted to the Human Research Ethics Committee of the Federal University of Santa Catarina, being approved on June 28, 2010 under the protocol no. 833/10. Along with the data collection process, the participants were invited to sign the Free and Informed Consent Form. Aiming at ensuring identity secrecy, the participants' names were replaced by the pseudonym "manager" associated to the Arabic number related to the interview order. Public managers were represented by the letters PM, PN and PS accordingly to the levels: municipal, national and state (1PM Manager, 2PN Manager, 3PS Manager). Private managers were represented as follows: $4 \mathrm{PR}$ Manager and 5PR Manager.

\section{RESULTS}

The analysis of the interviews conducted with managers pointed to the organization of outcomes into two themes: Considerations regarding 
the Unified Health System and Current situation and challenges for health management.

\section{Considerations regarding the Unified Health System}

The Unified Health System (SUS) is perceived by the participants as a great achievement and a victory of Brazilian people, and its consolidation should be a priority of the whole society aiming to constitute it as a State Policy and not merely a government program. They acknowledge that, in spite of insufficient resources, SUS has taken a big step forward after the enlargement of the Primary Health Care, the establishment and development of the Family Health Strategy (FHS) and the implementation of the Mobile Emergency Care Service (SAMU) and Emergency Care Units (UPA) and the expansion of the distribution of medicines. Nevertheless, it is still highly and problematically dependent on the private sector when in face of medium and high complexity cases. The logics related to profit and right to healthcare oppose, and the public-private partnerships have not been ruled by the public responsibility, as demonstrated by the following speeches: SUS is a victorious proposal, it was the greatest achievement of Brazilian people over recent years (Manager 2PN); Family Health Strategy is a great initiative, the opening of new UPAs or Outpatient services is amazing (Manager 4PR); Currently, in the case of a publicprivate relationship, the private sector assumes "the filet mignon" (in the sense of the most lucrative part of health care services) and the public sector only has the leftovers... this could not be so. It is required a strong regulator public sector and a private sector regulated accordingly to this logic; it should be a complement to all actions involved and not only for those which are profitable (Manager 2PN).

When questioned regarding health management in their activity location and at SUS (in national level), the participants classified management into one of the three options presented, as follows: outdated, updated and advanced. Outdated comprehends a management in which contemporary resources are not applied to planning areas, institutional organization, operational instruments and organizational performance assessment. Updated refers to the management in which contemporary instruments are applied to these areas. Advanced refers to the management which not only applies contemporary resources, but also develops and applies innovative initiatives (Figure 2). Managers from private and public (SUS - from municipal, state and national levels) sectors consider the management within the context under their responsibility as advanced or updated. Nonetheless, SUS management in national level, which includes a service network from several levels, was classified as outdated by $100 \%$ of the interviewees. This is significant, provided that SUS is the only resource available to most Brazilians for meeting their healthcare needs.

Figure 2 - Health management classification at the location of activity and SUS (in national level), accordingly to the participants involved in this study

\begin{tabular}{|c|c|c|}
\hline Participant & Management at their location of activity & SUS management in national level \\
\hline Manager 1 & Advanced & Outdated \\
\hline Manager 2 & Advanced & Outdated \\
\hline Manager 3 & Advanced & Outdated \\
\hline Manager 4 & Advanced & Outdated \\
\hline Manager 5 & Advanced & Outdated \\
\hline
\end{tabular}

\section{Current situation and challenges for health management}

All participants involved in this study agreed on the lack of professionals trained to act as managers of SUS. They pointed out as the source of the problem the weak technical training of healthcare professionals, as well as the discontinued and inefficient action of continuing education within this field. In addition, they highlighted the high turnover of managers particularly within the pub- lic area, and the difficulty of acting according to management models different from the traditional model, which is based on centralized, hierarchical and bureaucratized actions. As a consequence, the managerial capacity is far from meeting the needs and complexities related to healthcare. The following statements demonstrate these findings: what is the big issue I go through? It is training human resources who are fit and skilled for managing. [...] these people should be aware of new methods, new 
knowledge which has been added to the management field (Manager 1PM); SUS still sets a very authoritative relationship, although a participatory management is established as one of its doctrinal basis [...]. The undergraduate field requires a curriculum aimed towards the Brazilian reality, towards SUS and not towards a market-based system (Manager 2PN); managing a structure like this [hospitals] is somewhat difficult due to the lack of trained professionals in the labor market (Manager 5PR).

Concerning the implementation of administration tools, particularly in planning and assessment areas, managers have been highlighting the importance of daily planning related to health, provided that the strategic planning is mostly employed in the private area. The systematic assessment applied both to the institution and the quality of the healthcare provided is still incipient and it is pointed out as a practice to be strengthened aiming at achieving efficiency and effectiveness as regards healthcare services. The subjects mentioned accreditation/certification initiatives, such as the National Accreditation Organization (ONA), the Joint Commission International (JCI), as well as they also mentioned the implementation of the Balanced Score Card (BSC), users' satisfaction surveys and appreciation of the ombudsman's office, which were all pointed out as strategies for qualifying the service provided to the society, and also public oversight was mentioned as a method for ensuring high quality services, as exemplified in the following statements: such administration tools [planning and assessment] constitute another challenge for healthcare services [...] we encourage the National Ombudsman's office to rearrange its structure involving state and municipal components and we are going to provide financial support, [...] also establishing a management assessment, monitoring departments and strengthening the public oversight system (Manager 2PN); the last strategic planning we draft [...] is still in effect. Along with a consultant's help, we implemented the BSC, which means Balance Score Card, as a planning tool. [...] We also have a CR [Customer Relations Service] available (Manager $4 \mathrm{PR})$; we hope to maintain this qualification program at the hospital, as well as the certification and then we may even achieve ONA (Manager 5PR).

Managers appointed some factors related to health management which they consider innovative despite the incipience and difficulty in dissemination. Among these, they highlighted: computerizing of clinical records and areas of administrative and healthcare management, as well as the expectation towards the implementation of the National Health Card (CNS) as the embryo of a unique and national electronic clinical record. In addition, all interviewees involved perceive that career incentives which prize training and continuing education of professionals may contribute to the high quality of the services provided. Another factor mentioned by interviewees was the implementation of a Management Program (called Programa Mais Gestão in Brazil), which is financed by the Ministry of Health in partnership with several companies. This Program has provided training and exchange through the use of tools such as benchmarking in order to act as a reference for best practices, as illustrated by the following statements: the implementation of a health information system was decisive because without data I can't manage anything properly. It is essential having access to information technology (Manager 1PM); as regards to innovation, we have a managers' training program particularly targeted to SUS. The School of Public Health is innovative with specialization and emphasis in the Public Health System (Manager 3PS); when working at SUS organization, decentralization [...] hierarchy and regionalization [...] The CNS card is going to be strategic. This is because, through this card, the financial statement between cities will be possible [as regards to the distribution of resources] (Manager 2PN).

The interviewees also mentioned possible challenges and appointed solutions for issues and weaknesses, such as: the need for approval of the regulation provided in the Constitutional Amendment No. 29 (EC 29) (such approval was granted on December 07, 2011); finding methods for loss compensation resulting from the removal of the Temporary Contribution on Financial Transactions (CPMF); changing the current legislation which sets limits to the flexibility of health management. For the last mentioned issue, there were proposed changes on legislation and management outsourcing through institutions, such as, Social Organizations. Aiming at achieving efficiency and effectiveness for health management in Brazil, accordingly to principles and guidelines provided by SUS, the following factors were proposed: a continuous nationwide effort to provide training and/or professionalization of managers; substantial modernization through the use of electronic communication and information technologies; as well as, the reduction of the instability and high turnover of managers in the public sector resulting from political implications. 


\section{DISCUSSION}

\section{Unified Health System Consolidation}

Managers participating in this survey unanimously agreed in acknowledging the importance and greatness of SUS, as well as its need for consolidation. According to the $\mathrm{WHO},{ }^{11}$ the universal coverage of health services is the highest priority within this area. No country, regardless of its wealth, has been able to ensure to all population instant access to all technologies and actions, which can improve health and extend lifetime. In the poorest countries, just a few healthcare services are available to everyone. Unfairness is significantly aggravated with the difference set for people of higher and lower income as regards to accessing healthcare services. This consideration highlighted by the WHO reinforces the importance of the existence of SUS in Brazil.

SUS is a great achievement of the democratic struggle in Brazil; however, it is not consolidated yet. SUS consolidation comprehends the compliance with the mission of ensuring healthcare services to the entire population on a daily basis, universally, comprehensively, equitably, and such care should be decentralized, resolutive, for free, in high quality and also including social control. It is not about a utopian dream, but a strategic purpose to be pursued by and for Brazilian people. ${ }^{12}$

A portrait of healthcare services in Brazil ${ }^{13}$ displays SUS strongly present in Primary Health Care, but only holds $35.4 \%$ of hospital beds (2009) and $6.4 \%$ of Diagnostic and Therapeutic Support Services (2010). In 2008, among the 18.2 million people who had medical appointments, $76 \%$ had higher incomes and 59\% had lower incomes. ${ }^{13}$ Historically, medium and high complexity cases receive a significant amount of federal resources particularly in more economically developed regions. In this healthcare level, the gap found in the public sector coverage allows the private sector to provide the most expensive actions resulting in high profitability within an ever-expanding market. ${ }^{14}$

According to the Pan American Health Organization, "the contemporary crisis in healthcare systems reflects the discrepancy between an epidemiological situation controlled by chronic conditions and a social response which, by failing to ensure continuity to healthcare processes, only answers to acute conditions and events arising from acute exacerbations of chronic conditions in fragmented, episodic and reactive basis. Due to the lack of organization within healthcare systems, these are identified as fragmented systems". 15:15

Brazil is ranked as the world's 8th largest economy and has set the strategic goal of becoming the 5th global power. Therefore, it is important to think of which healthcare services we want and need based on the reality of the most developed countries and societies. According to data provided by the Organization for Economic Cooperation and Development ${ }^{4}$, the public investment in health care is low in Brazil, and this enhances the opinion expressed by managers participating in this survey that the consolidation of SUS should encompass financial resources, particularly public funding and a leap of quality in management. Moreover, investments are required to move towards making Primary Health Care Services universal and qualified, and to build-out a decentralized medium and high complexity services network. Furthermore, proper education and an appreciation of the healthcare staff are required, in addition to strengthening the participation and of social control.

\section{Challenges for health management}

All managers participating in this survey agreed that health management is one of the biggest issues and its transformation is a major challenge. They also highlighted the main weaknesses found, as follows: lack of qualification of professionals for exercising management activities, delay in implementing new information technologies and management and work organization processes. In addition, a number of barriers were identified in the public sector, set by legislation which restrict the agility required, as well as, the high turnover of managers due to the connection with partisans and electoral processes, resulting in discontinuity, ongoing renewals and lack of motivation of professionals and workers as a whole.

This survey was limited to the higher authority of hospitals and the executive level without including healthcare management areas, and 80\% of the managers interviewed were physicians and one was an administrator $(20 \%)$. This finding corresponds to the records described in the literature that physicians occupy the highest leadership and management roles and nurses are responsible for management functions within the operational and direct care areas, as well as in the access doors. In the USA, a survey conducted in 2008 concerning the profile of 2,046 members of managing boards in healthcare institutions revealed that $22 \%$ of them were physicians and $2.4 \%$ were nurses. ${ }^{16}$ 
In Brazil, the culture that any professional is able to manage and that management is learned through practice still prevails. Very few managers have been trained in programs for apprehension of knowledge and skills related to management, leading groups, encouraging motivation and contribution to the efficiency and effectiveness of organizations and improvement of life quality at work. ${ }^{17}$ Nursing is the only profession related to the healthcare field in which the discipline of management is included in the undergraduate curriculum, also involving practice activities. Nevertheless, a number of difficulties are still noticed as regards the use of management instruments, and the low participation of nurses in exercising macro decision-making power at healthcare institutions and at SUS is also reported. ${ }^{18}$

Healthcare work is very special and should meet the level of expectation, relevance and magnitude it represents for people. Healthcare requires an expanded view of global welfare and life quality. Several products and services currently available in the society often do not meet people's expectations and needs but, in such cases, despite feeling angry or dissatisfied, the individual passes over the problem.

Along the life cycle of individuals, there will always be moments when it is essential to provide healthcare services through timely and humanized actions. The improper use of healthcare resources results in losses and irreversible human sufferings.

In this regard, healthcare services should be guided accordingly to the perspective of a care system in which caregiving means "providing overall and ongoing assistance to the patient, bearing in mind that such individual is unique and irreplaceable. Hence, the caregiver should focus on this fact and, therefore, all the other aspects involved, either physical, psychological and spiritual, are also taken into account and integrate the healthcare provided, not only those aspects directly related to the illness itself". ${ }^{19: 767}$

Thus, it is understood that healthcare always involves two dimensions, one of them being technical-scientific and the other expressive, this means, it concerns the comprehensiveness perspective of the individual. Therefore, these dimensions are known as "technical-care" and "ethical-care". ${ }^{19}$

Organizations in society which produce several goods and services are increasingly rearranging themselves to meet their customers' expectations and needs, also developing strategies for knowledge production, innovation and retention, training and concern about the life quality of their employees. In addition, there is an atmosphere requiring greater social transparency and commitment to sustainability. Therefore, social control, a tool which allows integrating citizens to policysetting processes, expresses a form of governing in which citizens can act as political individuals able to guide and monitor government actions aiming at ensuring high quality services. ${ }^{20}$

It seems that the major challenge for health management is building or rebuilding health services so that these will be effectively focused on the healthcare needs of individuals, groups or communities. For this purpose, an extensive renewal both of the conception and practice of the current health management is required.

The increasing growth in healthcare expenditures throughout the world is evident, as well as it is known that traditional management methods are far from achieving an effective and efficient performance in the outcomes related to the healthcare services provided. WHO estimates that around $20 \%$ and $40 \%$ of the total healthcare expenditure is wasted by diverse forms of inefficiency ${ }^{1}$ and that there is a structural crisis of contemporary healthcare systems: "The healthcare systems currently prevailing throughout the world are failing because they are unable to follow up the trend of declining acute problems and rising chronic conditions. [...] The paradigm of acute treatment still prevails [...]. In order to deal with rising chronic conditions, it is imperative that healthcare systems overcome such prevailing model". 11:34

The fragmentation of healthcare services was diagnosed as the leading cause of failure. In the opinion of individuals and the overall population, fragmentation results in access barriers, discontinuity of care, healthcare provided in inappropriate areas, disorientation, low resolution of problems and lack of involvement in meeting patients' needs.

Such systemic fragmentation is reproduced through the caregiving models found within the organizations in which professionals work individually, preventing or restricting a comprehensive approach or even the consideration of the user as an individual and also favoring risks and adverse events, resulting in providing a service that lacks humanization and quality. The negative aspects of healthcare fragmented systems become evident through the isolation and lack of communication among services, irresponsibility towards the enrolled population, disconnection between healthcare levels and supporting services resulting in the discontinuity of the healthcare provided to the popu- 
lation, a fact that becomes reactive and episodic. ${ }^{15}$

An alternative which has been advocated as an effective solution for dealing with issues related to public sector management is the management outsourcing particularly to Social Organizations, as early mentioned in this survey by one of the private sector managers. Nevertheless, the results related to its implementation distancing from SUS principles and the literature also show several limitations and problems, such as: punctual actions and restricted involvement of the community in the social control, ${ }^{21}$ issues regarding people's management, with lack of career planning, jobs and wages, and significant informality concerning functional progression which impacts negatively on organizational performance and services' production. ${ }^{22}$

The organization of healthcare services into networks constitutes the renewed proposal for overcoming fragmented models and the policy of SUS is inspired on it. Following this logic, healthcare is defined as "a network composed of organizations which provide or make arrangements to provide equitable and comprehensive healthcare services to the population and which are willing to respond for clinical and economic outcomes, as well as for the health condition of the population under their responsibility". 15:17

A glimpse of the effectiveness of health systems into a network is given through the pursuit for a unique system of governance for several contexts, as well as through the integrated management of clinical, administrative and logistical support systems focused on people's management, aiming at ensuring the adequate number of responsible and appreciated workers. In addition, a result-based management is also recommended, this means, providing financial incentives in line with the network goals. ${ }^{15}$

Healthcare services related to integrated networks turn the vertical classification of levels inadequate, and this reinforces a mistaken concept concerning complexity upon establishing that the primary health care level is less complex than the others. Within the networks' context, hierarchy is replaced by polyarchy, which highlights a horizontal orientation related to healthcare networks with different technological densities, but without different levels of importance among service types. ${ }^{23}$

\section{CONCLUSION}

In conclusion, SUS is a nationally integrated healthcare network policy which is still to be further consolidated. It is a universal system but still requires further resources, stable funding and management able to bring its principles and guidelines into reality.

Ironically, the major challenge faced by SUS is becoming a "Unified Health System" indeed. Evidence suggests that the highest risk to healthcare in Brazil is the consolidation of two subsystems with contradictory logical and references, this means, the public sector (SUS) for the less favored majority and the private sector to the most favored people. Both the consolidation and the fragmentation of these two systems will result in a severely set back against the legislation and, mainly, it goes in the opposite direction of healthcare services provided throughout the world which pursue to overcome the fragmentation aiming at achieving a greater efficiency and providing the best service to population.

The challenges for public and private managers are huge and they are responsible for setting a model for healthcare services in Brazil in the upcoming years and for future generations. The renewal of health management in Brazil in accordance with the perspective of a permanent agenda for building a health system which meets the population's expectations and needs related to healthcare is the Brazilian people's longing and a mission for managers. Consolidating SUS as the healthcare system above mentioned is a high priority and a significant step towards a more solidary and fair country.

This study also demonstrated that investigating the opinion of managers concerning healthcare services is a promising route for understanding issues in this area. The survey design was limited to the perspective of the governmental executive leadership and the direction of leading private hospitals without the intention of exploring their respective specificities. This survey did not focus on areas related to the care management, as well as the diversity and complexity of micro-managerial areas. As regards these two limits above mentioned, the study suggests conducting new investigations targeted to expand both the scope and focus related to these objects.

\section{REFERENCES}

1. World Health Organization (WHO). Health Systems Financing: the path to universal coverage [internet]. Genebra (CH): WHO; 2010. [acesso 24 Jan 2013] Disponível em: http://www.who.int/ whr/2010/10_summary_en.pdf 
2. Confederação Nacional das Indústrias (CNI). Instituto Brasileiro de Opinião Pública e Estatística (IBOPE). Pesquisa CNI - IBOPE: retratos da sociedade brasileira: segurança pública. Brasília (DF): CNI, 2011.

3. Westin R. O que esperam os brasileiros. Folha de São Paulo. São Paulo (SP); 2010 Set 22. Caderno Especial Pelo País.

4. Organization for Economic Co-Operation and Development (OECD). Health at a glance 2009: released on December 8 [internet]. Dublin: OECD; 2009 [acesso 24 Jan 2013] Disponível em: http:// www.dohc.ie/press/releases/2009/20091208.html

5. Ministério da Saúde (BR). Secretaria de Atenção Especial à Saúde. Coordenação-Geral de Atenção Hospitalar. Reforma do sistema da atenção hospitalar brasileira. Brasília (DF): MS; 2004.

6. Campos GWS. Prefácio: reforma do modelo de gestão no Hospital Municipal Odilon Behrens. In: Araújo GF, Rates SMM, organizadores. Cogestão e humanização na saúde pública. Ijui (RS): UNIJUI; 2009. p. 23-4.

7. Cecílio LCO. A morte de Ivan Ilitch, de Leon Tolstói: elementos para se pensar as múltiplas dimensões da gestão do cuidado. Interface Comun Saúde Educ. 2009; 13(suppl.1):545-55.

8. Matos E, Pires D. Teorias administrativas e organização do trabalho: de Taylor aos dias atuais, influências no setor saúde e na enfermagem. Texto Contexto Enferm. 2006 Jul-Set; 15(3):508-14.

9. Triviños ANS. Introdução à pesquisa em ciências sociais: a pesquisa qualitativa em educação. São Paulo (SP): Atlas; 1987.

10. Minayo MCS. O desafio do conhecimento: pesquisa qualitativa em saúde. $11^{a}$ ed. São Paulo (SP): Abrasco; 2008.

11. Organização Mundial da Saúde (OMS). Cuidados inovadores para condições crônicas: os componentes estruturais de ação. Brasília (DF): Organização Mundial da Saúde; 2003.

12. Lorenzetti J. A enfermagem e os desafios para a saúde no Brasil: propostas para o período 2011-2015 [internet]. Florianópolis (SC): Coren/SC; 2011 [acesso 24 Jan 2013]. Disponível em: http:// www.corensc. gov.br/thumbs/file/documentoenfermagem.pdf

13. Paim J, Travassos C, Almeida C, Bahia L, Macinko
J. The Brazilian health system: history, advances, and challenges. Lancet. 2011 Mai; 377(9779): 1778-97.

14. Castro ALB, Machado CV. A política de atenção primária à saúde no Brasil: notas sobre a regulação e o financiamento federal. Cad Saúde Pública. 2010 Jan-Abr; 26(4): 693-705.

15. Organização Pan-Americana da Saúde (OPAS). A atenção à saúde coordenada pela APS: construindo as redes de atenção no SUS. Brasília (DF): Organização Pan-Americana da Saúde; 2010.

16. Khoury CM, Blizzard R, Wright Moore L, Hassmiller S. Nursing leadership from bedside to boardroom: a gallup national survey of opinion leaders. J Nurs Adm. 2011 Jul-Ago; 41(7): 299-305.

17. Amaral AEEHB. Gestão de Pessoas. In: Ibañez N, Elias PEM, Seixas PHD, organizadores. Política e gestão pública em saúde. São Paulo (SP): Hucitec Editora; 2011. p.553-85.

18. Almeida ML, Segui MLH, Maftum MA, Labronici LM, Peres AM. Instrumentos gerenciais utilizados na tomada de decisão do enfermeiro no contexto hospitalar. Texto Contexto Enferm. 2011;20(esp):1317.

19. Fracolli LA, Zoboli ELPC. Desafios presentes na qualificação do cuidado em saúde e humanização: conceitos e concepções. In: Ibañez N, Elias PEM, Seixas PHD, organizadores. Política e gestão pública em saúde. São Paulo (SP): Hucitec; 2011. p.762-80.

20. Sá MJCN, Porto MTDFPM. Controle Público e o SUS. In: Ibañez N, Elias PEM, Seixas PHD (organizadores). Política e gestão pública em saúde. São Paulo (SP): Hucitec; 2011. p.395-403.

21. Rezende CAP. O modelo de gestão do SUS e as ameaças do projeto neoliberal. In: Bravo MIS (Organizadora). Política de saúde na atual conjuntura: modelos de gestão e agenda para a Saúde. $2^{\mathrm{a}}$ ed. Rio de Janeiro (RJ): Rede Sirius/AdufrjSSind; 2008.

22. Barbosa NB, Elias PEM. Health social organizations as a way of public/private management. Ciênc Saúde Coletiva. 2010 Ago; 15(5): 2483-95.

23. Mendes EV. As redes de atenção à saúde: uma mudança na organização e na gestão dos sistemas de atenção à saúde. In: Vecina-Neto G, Malik AM. Gestão em saúde. Rio de Janeiro (RJ): Guanabara Koogan; 2011. p.32-49. 